\title{
RESEARCH PAPER \\ Castor seed yield at suboptimal soil moisture: Is it high enough?
}

\author{
Mali N. Buendía-Tamariz ${ }^{1}$, Ricardo Trejo-Calzada1', Ignacio Sánchez- \\ Cohen ${ }^{2}$, Arnoldo Flores-Hernández ${ }^{1}$, Miguel A. Velásquez-Valle ${ }^{3}$, and \\ Aurelio Pedroza-Sandoval ${ }^{1}$
}

${ }^{1}$ Universidad Autónoma Chapingo, Unidad Regional Universitaria de Zonas Áridas. Km. 38 Carretera Gómez Palacio-Chihuahua, Bermejillo, Durango, México. C.P. 35230.

${ }^{2}$ Instituto Nacional de Investigaciones Forestales Agrícolas y Pecuarias. Centro Nacional de Investigación Disciplinaria Relación Agua, Suelo, Planta, Atmósfera. Km 6.5 Margen Derecha Canal Sacramento, Gómez Palacio, Durango, México. C.P. 35140.

${ }^{3}$ Instituto Nacional de Investigaciones Forestales Agrícolas y Pecuarias Campo Experimental Saltillo. Carretera Saltillo - Zacatecas km 342+119 \# 9515, Hacienda de Buena Vista C.P. 25315

\begin{abstract}
M.N. Buendía-Tamariz, R. Trejo-Calzada, I. Sánchez-Cohen, A. Flores-Hernández, M.A. Velásquez-Valle, and A. Pedroza-Sandoval. 2019. Castor seed yield at suboptimal soil moisture: Is it successful?. Cien. Inv. Agr. 46(3): 253-265. This study discusses how soil moisture influences the seed yield of two castor plant varieties in an arid zone in Mexico. An experiment was set up with two factors: soil moisture, with three levels (high $=-0.05 \mathrm{MPa}$, medium $=-0.31 \mathrm{MPa}$ and low $=-0.91 \mathrm{MPa}$ ), and castor variety (Krishna and Rincon). The combination resulted in a factorial $3 \times 2$ experimental design. The experiment was set up as a randomized block with four replications under a split-plot arrangement, where the whole plots were for soil moisture and the subplots were for the castor variety. The measured variables were plant height (PH), days to flowering of $50 \%$ of the plants (DF), leaf area (LA), dry weight (DW), source-sink relationship, harvest index (HI) and seed yield. Data were analyzed by ANOVA, mean tests (HSD at $\alpha=0.05$ ) and regression analysis. There were significant differences in PH, LA, DW, HI and yield among the treatments. The values of PH, LA and DW tended to be higher at higher soil moisture levels than at lower moisture levels. The source strength was generally lower than the sink strength in all the treatments. There were significant differences between the varieties for HI, and the interaction between soil moisture and variety was also significant. Significant differences were found in yield; the Krishna variety had a greater yield than the Rincon variety, but there was only a significant difference between the yield of the Krishna variety cultivated under low soil moisture $\left(5200 \mathrm{~kg} \mathrm{ha}^{-1}\right)$ and that of the Rincon variety cultivated under high soil moisture $\left(2570 \mathrm{~kg} \mathrm{ha}^{-1}\right)$. The results of this study indicate that castor plants can be cultivated in arid regions at suboptimal soil moisture levels with supplementary irrigation without compromising plant performance or yield.
\end{abstract}

Key words: Plant growth, Ricinus communis L., seed yield, source-sink relationships, supplementary irrigation.

Received Nov 30, 2018. Accepted Sep 10, 2019.

Corresponding author: rtrejo@chapingo.uruza.edu.mx 


\section{Introduction}

The castor plant is a C3 plant of the Euphorbiaceae family (Webster, 1994). It is an oil-producing species and has long been appreciated for its important commercial value. It has more than 700 industrial uses (Anjani, 2012). Moreover, it shows promise for a variety of applications in the coming years, particularly as a source of renewable energy (Patel et al., 2016). Due to its great variability among genotypes, castor has adapted to a wide range of environmental conditions (Sowmya et al., 2016). It is cultivated in tropical and subtropical regions as a perennial shrub and in temperate climates as an annual plant (Bauddh et al., 2015). The castor oil plant is a hardy crop that is easy to establish in the field, resistant to drought, and tolerant of different types of soil, including marginal soils (Salihu et al., 2014). Recently, it has been proposed as an alternative for sustainable production under the severe conditions in the semiarid and arid regions of the world (Teixeira et al., 2017).

Approximately $65 \%$ of the land in Mexico is dry (UNESCO, 2010). In arid zones of Mexico, competition for water between sectors (agricultural, domestic, industrial) is increasing, which increases pressure on water resources. Water scarcity in arid areas mainly affects agriculture, which is considered the main user of water with a $75 \%$ utilization of the total water available (Molden et al., 2001). Therefore, a key strategy is to focus on improving water productivity by increasing crop productivity with a lower use of irrigation water (Tabarzad and Ghaemi, 2015).

Castor has shown tolerance to drought and salt stresses and has been cultivated under both rainfed and supplementary irrigation conditions (Sharma et al., 2010; Bauddh and Singh, 2012; Zhanga et al., 2018). Thus, a yield of $1774 \mathrm{~kg} \mathrm{ha}^{-1}$ of castor seeds was produced without irrigation, $2199 \mathrm{~kg} \mathrm{ha}^{-1}$ with supplementary irrigation at the end of the growing season, and $4252 \mathrm{~kg} \mathrm{ha}^{-1}$ with supplementary irrigation before and after the rainy season (Souza et al., 2007). Under optimized irrigation conditions, $3780 \mathrm{~kg} \mathrm{ha}^{-1}$ of hybrid GCH5 castor seeds were obtained (Raj et al., 2010). Castor showed greater water use efficiency under a dry irrigation regime than under a wet irrigation regime. However, the yield was higher $\left(2.13 \mathrm{t} \mathrm{ha}^{-1}\right)$ under the wet regime (Ramanjaneyulu et al., 2013). Lavanya et al. (2012) evaluated 15 genotypes of castor under rainfed conditions, and the highest yields of seeds and oil were $1580 \mathrm{~kg}$ $\mathrm{ha}^{-1}$ and $750 \mathrm{~kg} \mathrm{ha}^{-1}$, respectively.

In northeastern Mexico, Armendáriz et al. (2015) evaluated eleven genotypes of castor collected in different places in Mexico. The genotypes were grown under rainfed conditions, and yields ranged between 56.3 and $937.1 \mathrm{~kg} \mathrm{ha}^{-1}$, while oil production varied between 27 and $393 \mathrm{~kg} \mathrm{ha}^{-1}$. Solís-Bonilla et al (2016) evaluated eleven castor varieties from central and southeastern Mexico under rainfed conditions. They found significant differences in the days to flowering among the varieties (99 to 149 DAS). Variability has been found in castor varieties in terms of the morphological characteristics of the plant as well as the features of the clusters, especially fruits and seed size. Salazar Sánchez et al. (2014) used an F12 from a native genotype under a subsidiary irrigation system and two population densities. The yield was statistically similar for both population densities, with $3493 \mathrm{~kg} \mathrm{ha}^{-1}$ and $3569 \mathrm{~kg} \mathrm{ha}^{-1}$ for the low and high population densities, respectively.

It has been found that regulated low irrigation induces specific responses in some species based on the adaptation of plants to drought (Ma et al., 2015). These responses reduce irrigation water use and even increase crop productivity (Acevedo-Opazo et al., 2010). In some Ricinus communis varieties, it has been observed that deficit irrigation led to lower water consumption without affecting photosynthesis (Carvalho et al, 2019). It has been reported that different irrigation regimes applied to castor did not significantly affect the number of branches or the number of nodes (Ramanjaneyulu et al., 2013). However, there are not enough studies on the effects of 
suboptimal irrigation on the growth and yield of castor in arid environments. The aim of this study was to identify the responses of the growth and yield of two varieties of castor plant to different levels of soil moisture in an arid environment.

\section{Materials and methods}

Preliminary assays were carried out with four varieties of castor to evaluate their performance under irrigation in Durango, Mexico. These varieties were donated by the "Breeding of Ricinus communis project" of Universidad Autónoma Chapingo. Rincon and Krishna showed the best performance. As a result, these two varieties were selected for this study. A field experiment was conducted at Unidad Regional Universitaria de Zonas Áridas of Universidad Autónoma Chapingo, Mexico. It is located at $25^{\circ} 53^{\prime} \mathrm{N}, 103^{\circ} 36^{\prime}$ $\mathrm{W}$ and an altitude of 1,117 meters above sea level in a region known as Comarca Lagunera. This region has a dry climate with summer rains, an average annual rainfall of $239 \mathrm{~mm}$, and a thermal oscillation from 7 to $17{ }^{\circ} \mathrm{C}$ (García, 1973). The physicochemical characteristics of the soil were analyzed. It has a clay-loam texture, apparent density of $1.2 \mathrm{~g} \mathrm{~cm}^{-3}$, electrical conductivity of $2.6 \mathrm{dS} \mathrm{m}^{-1}$ and $\mathrm{pH}$ of 8.1. The available nitrogen was $16.3 \mathrm{mg} \mathrm{kg}^{-1}$, the available phosphorus was $12 \mathrm{mg} \mathrm{kg}^{-1}$ and the available potassium was 401 $\mathrm{mg} \mathrm{kg}^{-1}$. No fertilizers were added to the soil for this experiment.

\section{Experimental design}

Two factors were included in the experiment: soil moisture, with three levels (high $=-0.05 \mathrm{MPa}$, medium $=-0.31 \mathrm{MPa}$ and low $=-0.91 \mathrm{MPa})$, and two varieties (Krishna and Rincon). The combination resulted in a factorial $3 \times 2$ experimental design. The experiment was set up in a randomized block design with four replications under a split plot arrangement, where the whole plots were for soil moisture and the subplots were for variety. The treatments were identified with the following abbreviations: KH, KM and KL for the Krishna variety under conditions of high, medium and low soil moisture, and RH, RM and $\mathrm{RL}$ for the Rincon variety under conditions of high, medium and low soil moisture. The sowing date was June 30, 2016. The population density was 13,888 plants $^{-1}{ }^{-1}$, which corresponded to seedbeds with black plastic film mulch that was $1.20 \mathrm{~m}$ wide with a separation of $0.60 \mathrm{~m}$ between plants. The experimental unit consisted of four seedbeds that were $9 \mathrm{~m}$ long and $1.2 \mathrm{~m}$ wide. The useful plot corresponded to the 7 central meters from the two central seedbeds. The climatic conditions during the growing season were the following: average temperature of $22^{\circ} \mathrm{C}$, relative humidity of $56 \%$ and an accumulated precipitation (June-December 2016) of $261 \mathrm{~mm}$.

\section{Establishment of the experiment and irrigation system}

The varieties of castor plant were manually sown in the field. A tape-type drip irrigation system was used, placing the lines on the soil surface with a controlled operating pressure of 16 PSI. A drip irrigation system was established, derived from a main line pipe and side connections of PVC for each plot. The drip irrigation system was controlled by a stopcock that allowed the delivery of water according to the irrigation program with water drawn from a deep well. After sowing, and once the plants reached 15 to $20 \mathrm{~cm}$ in height (at 39 days after sowing, DAS), an initial watering was applied to reach the field capacity of the soil. Subsequently, the treatments for soil moisture content were initiated based on the irrigation program of each treatment.

\section{Soil moisture treatments}

For the soil moisture content treatments, the determinations of the soil field capacity (FC) and the permanent wilting point (PWP) were performed 
in the lab. The $\mathrm{FC}$ was $27 \%$ soil moisture $(-0.025$ $\mathrm{MPa})$, while the PWP was $13 \%$ (-1.36 MPa). With this information, a calibration curve of the percentage soil moisture content against the pressure in Megapascals (MPa) was obtained. In addition, we proceeded to apply irrigation to increase the soil water content up to FC. Afterwards, the soil water content was managed according to each specific treatment. Irrigation times were established to perform the treatments. To maintain a favorable moisture content, soil moisture was lowered to a maximum of $24 \%(-0.048 \mathrm{MPa}$, near field capacity), $18 \%$ (-0.31 MPa) and 14\% (-0.908 $\mathrm{MPa}$ near permanent wilt point) for the high, medium and low soil moisture treatments, respectively, recovering the humidity at $27 \%(-0.025 \mathrm{MPa})$ for both varieties.. The soil moisture content was periodically measured at $30 \mathrm{~cm}$ depth by the gravimetric method. At the end of the study, the total applied irrigation was calculated as 64, 51 and $36 \mathrm{~cm}$ on average for the high, medium and low soil moisture treatments, respectively.

\section{Measured variables}

The variables measured were plant height (PH), days to flowering of $50 \%$ of the plants (DF), leaf area (LA), plant dry weight (DW), source-sink relationship, harvest index (HI) and seed yield (Y). The variables of fresh and dry matter were evaluated by selecting and identifying plants at random within each treatment at the end of the experiment, and the seed yield variable $\left(\mathrm{kg} \mathrm{ha}^{-1}\right)$ was evaluated by considering the seeds of the fruits of the experimental plot.

For dry weight, the parts of the plant were placed into an oven with forced air at $64{ }^{\circ} \mathrm{C}$ for 72 hours or until constant weight. The leaf area per plant was determined using an LI-3000C portable area meter. The harvest index (HI) was determined by the following equation:

$$
\mathrm{HI}=\frac{\mathrm{HDM}}{\mathrm{TDM}}
$$

where HDM is harvestable dry matter $(\mathrm{g})$ and TDM is total dry matter ( $\mathrm{g}$ ).

The net assimilation rate (NAR, $\mathrm{g} \mathrm{cm}^{2} \mathrm{~d}^{-1}$ ) was calculated using the values of dry weight and leaf area as follows:

$$
N A R=\frac{(\mathrm{W} 2-\mathrm{W} 1)(\ln \mathrm{LA} 2-\ln \mathrm{LA} 1)}{(\mathrm{T} 2-\mathrm{T} 1)(\mathrm{LA} 2-\mathrm{LA} 1)}
$$

where $\ln =$ natural logarithm, LA1, 2 = leaf area at the beginning and end of the time interval, W1, 2 = dry weight at the beginning and end of the time interval, and T1, 2 = initial and final time interval.

Additionally, the relative growth rate (RGR ( $\mathrm{g} \mathrm{g}^{-1}$ $\mathrm{d}^{-1}$ ) was calculated using the following equation:

$R G R=\frac{(\ln \mathrm{W} 2-\ln \mathrm{W} 1)}{(\mathrm{T} 2-\mathrm{T} 1)}$

where $\ln =$ natural logarithm, $\mathrm{W} 1,2=$ dry weight at the beginning and end of the time interval, and $\mathrm{T} 1,2$ = initial and final time interval.

The source-sink relationship was estimated by the following equations:

$\mathrm{SS}=\mathrm{LA} * \mathrm{NAR}$

$\mathrm{SKS}=\mathrm{DW} * \mathrm{RR}$

where SS = source strength, (g d-1), LA = Leaf area, $\mathrm{NAR}=$ net assimilation rate, $\mathrm{SKS}=\operatorname{sink}$ strength (g d-1), DW = dry weight, and RGR = relative growth rate.

\section{Data analysis}

To interpret the quantitative variables, ANOVA was applied. In those cases in which there were significant differences between the treatments, the Tukey comparison test (HSD) was used, 
and a regression analysis adjusted to the logistic model for the evaluated variables was performed. Statistical analysis was performed using RStudio software.

\section{Results and discussion}

Ricinus communis L. is a plant that has multiple uses, as various parts of the plant can be used in agricultural, industrial, medical, and ornamental fields. It is an excellent candidate for the production of high-value industrial and agricultural raw material (Rukhsar et al., 2018). Additionally, it has been reported as a good crop for marginal soil, such as that in semiarid areas (Severino et $a l ., 2012)$. In this study, we tested two varieties at different soil moisture levels in order to evaluate their agronomic performance and seed yield.

The data analysis for the days to flowering showed no significant differences (HSD $\alpha=0.05$ ) among the treatments applied. However, in both varieties, the highest soil moisture treatment led to fewer days to the flowering period than those in treatments with lower soil moisture. The number of days to flowering in both varieties was between 84 and 87 DAS without significant differences between the varieties. In other experiments, blooms were reported from 48-68 days (Anjani et al., 2018) and 47-51 days (Rukshar et al., 2018). The number of days to flowering of eleven varieties in a temperate region of Mexico ranged between 99 and 149 DAS (Solis Bonilla et al., 2016). The flowering of the varieties evaluated in our experiment was within the range reported in other studies. However, seed production may not be influenced by fast flowering and may be influenced by other characteristics related to with the maturity of the raceme or the amount of capsules, as reported by Rukhsar et al. (2018). In addition, Severino et al. (2012) mentioned that high temperatures affect the ratio of female to male flowers, but that ratio would not necessarily increase seed yield.

Regarding plant height, significant differences (HSD $\alpha=0.05$ ) among the treatments were observed. In general, the Rincon variety had lower heights than those in the Krishna variety. In the same way, based on the logistic model equation used, the treatment of the Krishna variety with high soil moisture $(\mathrm{KH})$ showed the highest growth rate with respect to height in the evaluated period, with a maximum of $7.2 \mathrm{~cm} \mathrm{day}^{-1}$ at 90 DAS. On the other hand, the treatment of the Rincon variety with low soil moisture (RL)

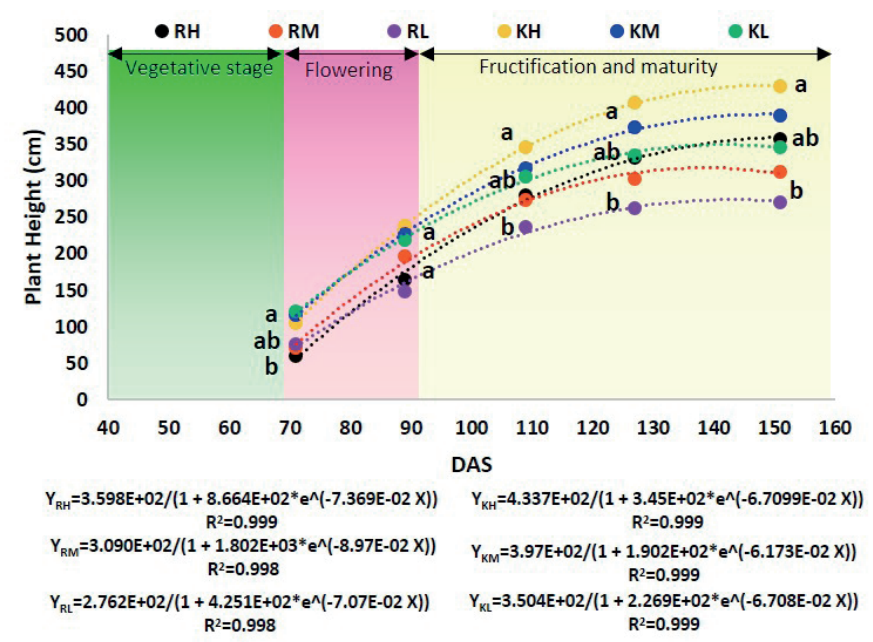

Figure 1. Plant height of two varieties of castor plant $(\mathrm{K}=\mathrm{Krishna}, \mathrm{R}=\mathrm{Rincon})$ at three levels of soil moisture $(\mathrm{H}=$ High, $\mathrm{M}=$ Medium, $\mathrm{L}=$ Low $)$ on five sampling dates $(71,89,109,127$ and 151 days after sowing). Different letters indicate significant differences (HSD at $\alpha=0.05$ ). 
had the lowest growth rate, with a final height of $270 \mathrm{~cm}$. The results indicate that soil moisture affects plant height in both varieties. Therefore, at higher soil moisture, greater plant height was observed (Figure 1).

These findings contrast with those reported by Kowser (2018) and by Souza et al. (2018), who attained heights of less than two meters in the genotypes and hybrids they used (genotypes DCH-177 and DCH-519; castor hybrids K93, respectively), indicating that the plant height largely depend on the genotype or variety. The heights reported in the present study may also be due to the spacing between plants, since studies such as that of Shinde et al. (2018) report that lower spacing between plants favors a greater height. Furthermore, soil moisture may also favor plant height. In addition, soil moisture can also determine plant height; low water availability inhibits the elongation of cells that affect various physiological and biochemical processes (Jaleel et al., 2008), affecting plant height, leaf area, stem diameter, and plant growth in different crops (Farooq et al., 2009).

The leaf area increased during the experiment. There were significant differences among treat- ments only at 116 and 167 DAS. According to the equation of the logistic model used for the leaf area, the treatment with the Rincon variety under high soil moisture presented the highest growth rate, followed by the Krishna variety under medium soil moisture. It is noteworthy that the Rincon variety had a larger leaf area when subjected to high soil moisture conditions than under lower soil moisture conditions, while the Krishna variety under the same high soil moisture conditions showed a significantly lower leaf area than that of the Rincon variety (Figure 2). However, the Krishna variety presented greater leaf area growth rates from the beginning of the experiment until 116 DAS, the stage in which flowering and fruit formation occurs. It is likely that this high leaf area growth rate favored seed yield, as has been reported in beans (Polón-Pérez et al., 2017).

The leaf area reported in this study is higher than that in the results reported by Fioreze et al. (2018). They reported leaf areas of up to $6500 \mathrm{~cm}^{2}$ at 90 days that subsequently decreased, while in our study, leaf area continued to increase (Figure 2). This may be due in part to the availability of water and nutrients, since plants with greater water availability tend to present larger leaf areas

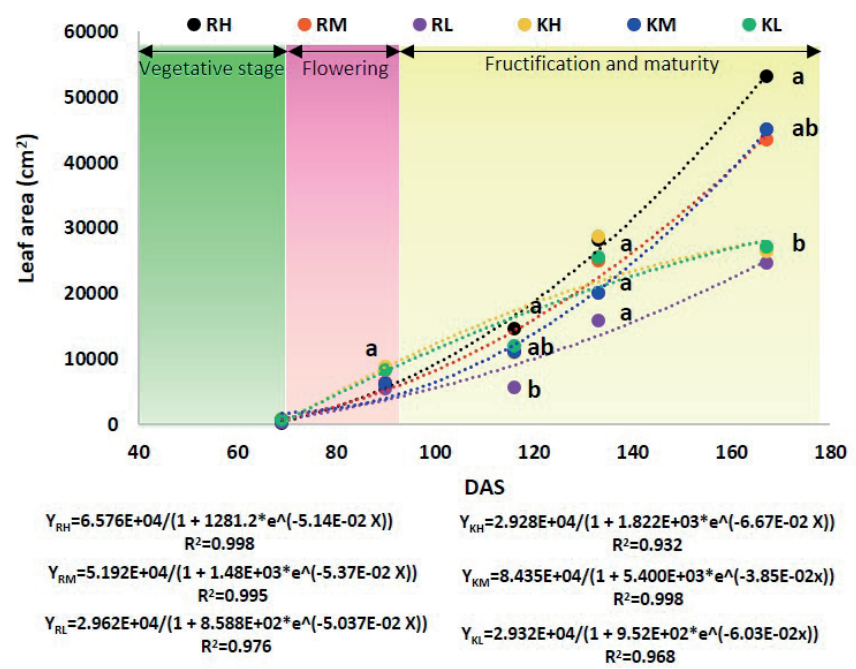

Figure 2. Leaf area (LA) per plant of two varieties of castor plant $(K=K$ rishna, $R=$ Rincon $)$ at three levels of soil moisture $(\mathrm{H}=$ High, $\mathrm{M}=$ Medium, $\mathrm{L}=\mathrm{Low})$ on five sampling dates $(69,90,116,133$ and 167 days after sowing). Different letters indicate significant differences (HSD at $\alpha=0.05$ ). 
and higher growth rates. Another cause may be the differences among varieties, as mentioned by Jiménez-Ocampo et al. (2015). Castor has been recognized as a species with high plasticity in plant height, leaf morphology, life cycle duration and seed morphology among genotypes (Sowmya et al., 2016). At the end of the growth cycle, early frosts were absent in the region where the experiment was set up. This may have allowed continuous growth and expansion of the leaf area in both varieties of castor plant.

Significant differences were found for dry weight at 133 and 167 DAS, favoring in general the treatments of the Krishna variety (HSD $\alpha=0.05$ ). The behavior of dry weight was similar to that of the leaf area. The treatments of the Krishna variety with medium soil moisture and the Rincon variety with high and medium soil moisture presented the highest dry weights in the end (167 DAS). The Rincon variety with low soil moisture had the lowest dry weight (Figure 3). These differences in dry weight are believed to be related to the differences in the leaf area, as reported in several studies in beans (Polón-Perez et al., 2017), in which the leaf area and dry weight are related. Additionally, the differences may be due to the greater number of secondary stems, since they accumulate a greater biomass than the leaves, as reported by Reddy and Matcha (2010). The low increments in dry weight at the end of the experiment in the KL and RL treatments may be attributed to a lower availability of water in the soil.

Regarding the source-sink relationship, both varieties presented a constant demand for assimilates regardless of the soil moisture, especially towards the end of the sampling period (Figure 4). The demand for assimilates in the Rincon variety is believed to be more focused on the vegetative growth of the plant rather than on the transfer of photosynthates to the reproductive organs. The same pattern seems to have happened in the Krishna variety with medium soil moisture. Fioreze et al., 2016 mention that there is competition between sinks, such as between the flowering of the primary bunch and that of the secondary stems, in early development.

In addition, the strength of the source was higher in the KH and KL treatments at 116 DAS, which could have favored the formation of reproductive organs as well as a photosynthetic apparatus that favors the use of photosynthates for the formation and filling of grain at later growth stages. According to Severino et al., 2012 and Fioreze et al., 2018, the manipulation of plant growth through the elimination of secondary stems promotes high yield due to the resulting higher growth and production of the primary bunch,

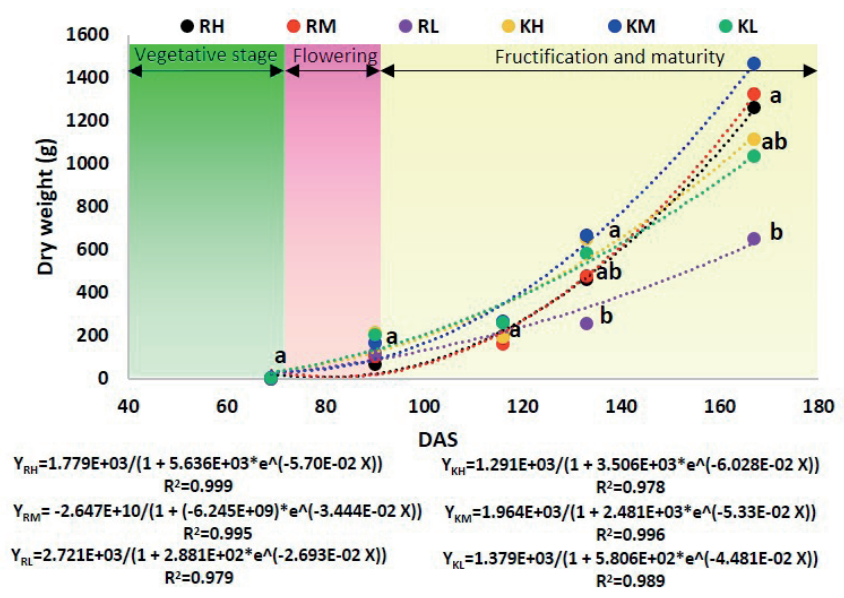

Figure 3. Dry weight (DW) of two varieties of castor plant $(K=$ Krishna, $R=$ Rincon $)$ at three levels of soil moisture $(\mathrm{H}=$ High, $\mathrm{M}=$ Medium, $\mathrm{L}=$ Low) on five sampling dates $(69,90,116,133$ and 167 days after sowing). Different letters indicate significant differences (HSD at $\alpha=0.05$ ). 


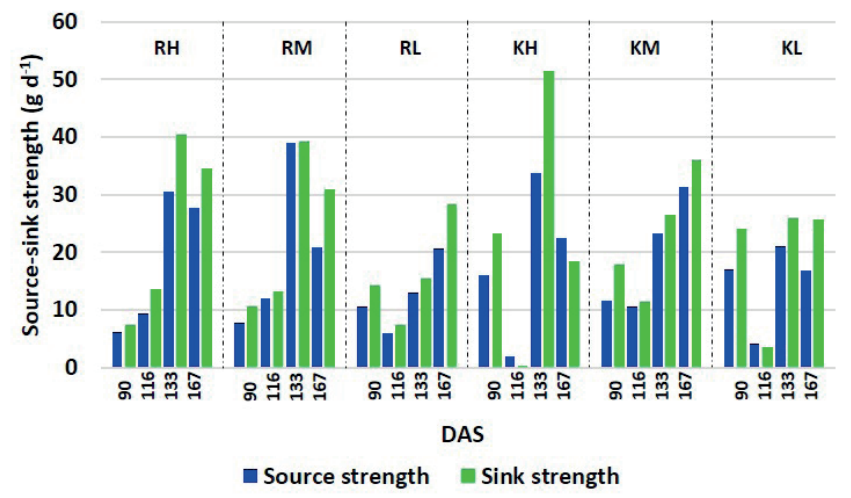

Figure 4. Source-sink relationship of two varieties of castor $(K=$ Krishna, $R=$ Rincon) at three levels of soil moisture $(\mathrm{H}=$ High, $\mathrm{M}=$ Medium, $\mathrm{L}=\mathrm{Low})$.

shorter growth cycle and more uniform maturity, which are considered key characteristics for the success of the crop. Therefore, we believe that the KH and KL treatments, by developing fewer secondary stems, focused the nutrient demand on grain filling. Additionally, the low source capacity throughout almost the whole growth cycle of the varieties evaluated in this study (Figure 4) reveals that more work must be done to improve the capacity of the source, for example, by management practices (fertilization, sowing date, population density, etc.) mainly before and during grain filling, as proposed for other crops (Bonelli et al., 2016).

Regarding the harvest index (HI), there were significant differences among varieties $(p=0.01)$ as well as differences related to the variety*soil moisture interaction $(p=0.03)$. The Krishna variety under low and high humidity conditions

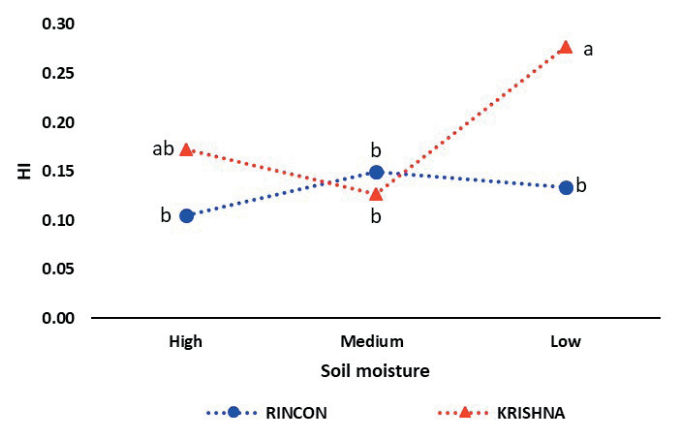

Figure 5. Harvest index of two varieties (Rincon and Krishna) of castor plants at three levels of soil moisture. Different letters indicate significant differences (HSD at $\alpha$ $=0.05$ ).
(KL and KH, respectively) had the highest $\mathrm{HI}$ values, of 0.28 and 0.17 , respectively. The treatments with the Rincon variety, RH, RM and RL (HIs of $0.10,0.15$ and 0.13 , respectively), as well as the KM treatment reported lower harvest index values. (Figure 5). The treatments with greater leaf area were those with lower HI values. This may be explained by the results of modeling studies that have shown that ramification and leaf production may produce a negative impact on source-sink relationships and reduce the grain yield (Julien et al., 2011). The harvest index of the Krishna variety under low moisture is comparable with that of other grains such as corn (0.32-0.36, Kumar et al., 2018a), so we can consider that this treatment had a good harvest index.

In addition, Kumar et al. (2018b) reported a harvest index of 0.31 in varieties of Ricinus communis, while Ramanjaneyulu et al. (2013)

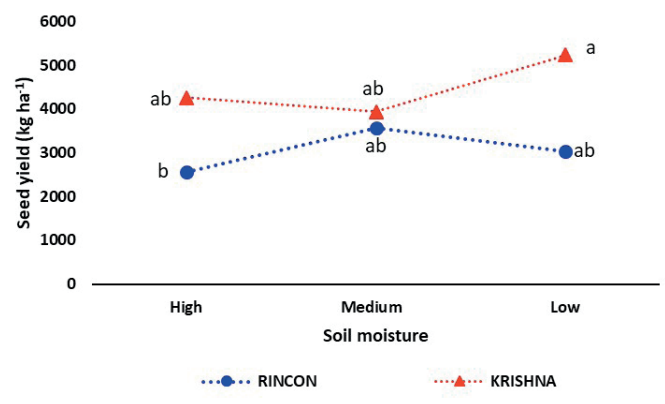

Figure 6. Seed yield of two varieties (Rincon and Krishna) of castor at three levels of soil moisture. Different letters indicate significant differences (HSD at $\alpha=0.05$ ). 
reported harvest index ranges of $0.29-0.31$. This suggests that the Krishna variety has a high yield potential considering that the crop requires minimal agricultural intervention; it is likely that with fertilization and other agricultural practices, such as those mentioned by Fioreze et al., 2018, the grain yield and harvest index of the Krishna castor variety can be increased.

Significant differences in seed yield among varieties were found $(p=0.004)$. The KL treatment had the highest yield, $5220 \mathrm{~kg} \mathrm{ha}^{-1}$. In general, the Krishna variety presented higher yields than the Rincon variety regardless of the soil moisture treatment, although the Krishna treatments only differed significantly from the high soil moisture treatment of the Rincon variety $(\mathrm{RH})$. The Krishna variety did not require high amounts of soil moisture to produce a good yield, and the low availability of water allowed it to deposit reserves in the seeds (Figure 6).

The yields that were obtained, especially those in the $\mathrm{KL}$ and $\mathrm{KH}$ treatments, are higher than those reported by Shinde et al. (2018) and Man et al. (2017) and are even comparable with those obtained by the fourteen genotypes studied by Shah et al. (2017). These yield results are believed to be partly due to the adequate development of the castor plant photosynthetic apparatus (90133 DAS) and partly due to the formation of photosynthates and their translocation towards flowering and the formation and filling of fruit, rather than towards the formation of other plant parts, such as more vegetative area, as in the case of the Rincon variety. Figure 2 shows that none of the treatments reached the maximum leaf area. This means that the plants could continue growing and producing seeds. However, the leaves of the KL treatment almost reached the maximum leaf area. It is possible that low soil moisture caused a shortening of the growth cycle in the Krishna variety in which more assimilates were translocated for grain filling, while high soil moisture may have caused an extension of the growth cycle in which more assimilates were directed towards leaf growth.

Moreover, several studies have indicated that populations of the same species may have similar levels of phenotypic plasticity for a certain characteristic, but there may be intrapopulation differences in the phenotypic plasticity of another characteristic (Ramírez, 2010). For example, the osmotic adjustment related to the adaptive response to hydric deficits (Turner, 2018) is a trait that can be inherited and positively associated with yield (Babita et al., 2010; Blum, 2017). For this reason, we also believe that the phenotypic plasticity of the plant played an important role in the evaluated varieties by generating anatomical, physiological, morphological or structural changes that allowed the varieties to adapt in different ways to the generated environments (in our case, different soil moisture levels).

The main conclusions are as follows. Based on the results, we can conclude that Ricinus communis $\mathrm{L}$. is a versatile plant that can adapt to the climatic conditions of the arid zones of Mexico and that it has great potential for cultivation on marginal lands with few nutrients and low water availability, given that in this study, the best result in terms of seed yield was obtained at suboptimal soil moisture levels. The Krishna variety has better performance characteristics and adaptation to prolonged water deficits than the Rincon variety, which is a common situation in arid areas. Among the treatments tested in this study, the treatment with the Krishna variety under conditions of low soil moisture (KL) obtained the best seed yields, a situation that was favored by the growth of an adequate photosynthetic apparatus from the 90 to 133 DAS period during which flower formation and fruit filling occurred. We conclude that castor can be produced in arid regions at suboptimal soil moisture levels without compromising plant performance or seed yield. 


\section{Resumen}

M.N. Buendía-Tamariz, R. Trejo-Calzada, I. Sánchez-Cohen, A. Flores-Hernández, M.A. Velásquez-Valle, y A. Pedroza-Sandoval. 2019. Rendimiento de semilla de higuerilla en condiciones subóptimas de humedad: ¿Es suficiente? Cien. Inv. Agr. 46(3): 253-265. En este estudio se analiza cómo la humedad del suelo influye en el rendimiento de las semillas de dos variedades de plantas de higuerilla en una zona árida de México. Se estableció un experimento incluyendo dos factores: humedad del suelo con tres niveles (Alto $=-0.05 \mathrm{MPa}$, Medio $=-0.31$ MPa y bajo $=-0.91 \mathrm{MPa}$ ) y variedades (Krishna y Rincon). La combinación resultó en un factorial $3 \times 2$. El diseño experimental fue un bloques al azar con arreglo en parcelas divididas, donde la parcela grande correspondió a la humedad del suelo y la subparcela a las variedades de higuerilla. Las variables medidas fueron altura de planta $(\mathrm{PH})$, días a floración (DF), área foliar (LA), peso seco (DW), relaciones fuente demanda, índice de cosecha (HI) y rendimiento. Los datos fueron analizados mediante análisis de varianza, pruebas de medias (HSD at $\boldsymbol{\alpha}=$ 0.05) y análisis de regresión. Se detectaron diferencias significativas en PH, LA, DW, HI y rendimiento. Los valores de PH, LA y DW tendieron a ser mayores en condiciones de alta humedad. La fuerza de la fuente en general fue menor que la fuerza de la demanda en todos los tratamientos. El HI y la interacción $\mathrm{HI}^{*}$ variedad mostró diferencias significativas entre tratamientos. Los rendimientos de la variedad Krishna fueron mayores que los de la variedad Rincon pero solo hubo diferencias significativas entre Krishna en condiciones de baja humedad (5200 kg ha $\mathrm{kg}^{-1}$ y Rincon en condiciones de alta humedad (2570 kg ha-1). Los resultados de este estudio apoyan que la higuerilla puede ser cultivada en regiones áridas en condiciones de humedad subóptima sin que se ponga en riesgo el desarrollo de la planta ni el rendimiento.

Palabras clave: Crecimiento de planta, relaciones fuente-demanda, rendimiento de semilla, Ricinus communis L., riego suplementario.

\section{References}

Acevedo-Opazo, C., S. Ortega-Farias, and S. Fuentes. 2010. Effects of grapevine (Vitis vinifera L.) water status on water consumption, vegetative growth and grape quality: An irrigation scheduling application to achieve regulated deficit irrigation. Agricultural Water Management, 97(7):956-964.

Anjani, K. 2012. Castor genetic resources: a primary gene pool for exploitation. Industrial Crops and Products 35(1):1-14.

Anjani, K., M.A. Raoof, M.S.L. Prasad, P. Duraimurugan, C. Lucose, P. Yadav, and C. Sarada. 2018. Trait-specific accessions in global castor (Ricinus communis L.) germplasm core set for utilization in castor improvement. Industrial Crops and Products 112:766-774.

Armendáriz, J., M. Lapuerta, F. Zavala, E. García-
Zambrano, and M.C. Ojeda. 2015. Evaluation of eleven genotypes of castor oil plant (Ricinus communis L.) for the production of biodiesel. Industrial Crops and Products 77(2015):484-490.

Babita, M., M. Maheswari, L.M. Rao, A.K. Shanker, and D.G. Rao. 2010. Osmotic adjustment, drought tolerance and yield in castor (Ricinus communis L.) hybrids. Environmental and Experimental Botany 69(3):243-249.

Bauddh, K., and R.P. Singh. 2012. Cadmium tolerance and its phytoremediation by two oil yield ing plants Ricinus communis (L.) and Brassica juncea (L.) from the contaminated soil .Int. J. Phytorem.14:772-785.

Bauddh, K., K. Singh, B. Singh, and R.P. Singh. 2015. Ricinus communis: A robust plant for bioenergy and phytoremediation of toxic metals from contaminated soil. Ecological Engineering 84(2015):640-652. 
Blum, A. 2017. Osmotic adjustment is a prime drought stress adaptive engine in support of plant production. Plant, Cell and Environment 40(1):4-10.

Bonelli, L.E., J.P. Monzon, A. Cerrudo, H. Rizzalli, and F. Andrade. 2016. Maize grain yield components and source-sink relationship as affected by the delay in sowing date. Field Crops Research 198(2016):215-225.

Carvalho, M., F.A. Roza, M.S. Mielke, A.A.F. de Almeida, L.M.C. Gomes, and F.P. Gomes. 2019. Ricinus communis L.: Water Use Efficiency, Carbon Assimilation and Water Relations on Deficit Irrigation. Journal of Experimental Agriculture International, 1-15.

Fioreze, S.L., A.C.D.C. Lara-Fioreza, L.G. Pivetta, J.D. Rodrigues, and M.D. Zanotto. 2016. Características agronômicas da mamoneira afetadas pelo método de condução de plantas e densidade de semeadura. Revista Ciência Agronômica 47(1):86-92.

Fioreze, S.L., A.C.D.C. Lara-Fioreze, L.G. Pivetta, J.D. Rodrigues, and M.D. Zanotto. 2018. Influence of the limitation of axillary bud growth on grain and oil yield of castor bean hybrids. Revista Ceres 65(2):127-134.

García de M., E. 1973. Modificaciones al sistema de clasificación climática de Köppen: Para adaptarlo a las condiciones de la República Mexicana. Universidad Nacional Autónoma de México. México. 246 p.

Jaleel, C.A., R. Gopi, B. Sankar, M. Gomathinayagam, and R. Panneerselvam. 2008. Differential responses in water use efficiency in two varieties of Catharanthus roseus under drought stress. Comptes Rendus Biologies, 331(1):42-47.

Jiménez Ocampo, R., R.R. Serna, C. Francisco, G. Villanueva, R.J. Regalado, and P.A.D. Martínez. 2015. Rendimiento de variedades e híbridos de higuerilla cultivados en diferentes ambientes de Durango, México. AGROFAZ 15(1):135-146.

Kowser, T., A.S. Halepyati, B.M. Chittapur, A.S. Channabasavanna, I.S. Goud, and B. Gowda. 2018. Effect of Genotypes on Spacing and Nipping with Different Levels of Nutrients on Growth and Yield of Castor (Ricinus communis
L.). International Journal of Pure and Applied Bioscience 6(1):1259-1265.

Kumar, M., A.C. Shivran, R. Chouhan, and K.C. Verma. 2018a. Effect of Sulphur Levels on Growth Attributes and Yield of Castor-Mungbean Intercropping System under Dryland Conditions. Findings in Agricultural Research and Management (FARM) Journal 2(1):9-13.

Kumar, P., M. Kumar, K. Kishor, and R. Kumar. 2018b. Effect of nutrient management on yield and yield attributes of Maize (Zea mays L.) under different tillage practices. Journal of Pharmacognosy and Phytochemistry 7(2):807-810.

Lavanya, C., I.Y.L.N. Murthy, G. Nagaraj, N. and Mukta. 2012. Prospects of castor (Ricinus communis L.) genotypes for biodiesel production in India. Biomass and Energy 39 (2012):204-209.

Ma, S.C., A.W. Duan, R. Wang, Z.M. Guan, S.J. Yang, S.T. Ma, and Y. Shao. 2015. Root-sourced signal and photosynthetic traits, dry matter accumulation and remobilization, and yield stability in winter wheat as affected by regulated deficit irrigation. Agricultural Water Management, 148:123-129.

Man, M.K., A.U. Amin, K.M. Choudhary, and A.D. Gora. 2017. Response of Castor (Ricinus communis L.) To Varying Weather Variables and Crop Geometry with Levels of Nitrogen under Rabi Season. International Journal of Current Microbiology and Applied Sciences 6(5):2409-2418.

Molden, D.J., U.A. Amarasinghe, and I. Hussain. 2001. Water for rural development: Background paper on water for rural development prepared for the World Bank (Vol. 32). IWMI.

Patel, V.R., G.G. Dumancas, L.C. Viswanath, R. Maples, and B.J. Subong. 2016. Castor Oil: Properties, Uses and Optimization of Processing $\mathrm{Pa}-$ rameters in Comercil Production. Lipis Insights 9:1-12.

Polón-Pérez, R., M. Ruiz-Sánchez, A. MirandaCaballero, and M.A. Ramírez-Arrebato. 2017. Effects of Water Stress on Grain Yield in the Vegetative Phase of bean Cultivation (Phaseolus vulgaris L.). Revista Ciencias Técnicas Agropecuarias 26(1):66-70. 
Raj, A.D., B.S. Patel, R.S. Mehta. 2010. Effect of irrigation methods on growth and economics of hybrid varieties of castor. Indian J. Agric. Sci. 80:795-800.

Ramanjaneyulu, A.V., A.V. Reddy, and A. Madhavi. 2013. The impact of sowing date and irrigation regime on castor (Ricinus communis L.) seed yield, oil quality characteristics and fatty acid composition during post rainy season in South India. Industrial crops and products 44:25-31.

Ramírez, J.A. 2010. Plasticidad fenotípica y diferenciación genética inter- e intrapoblacional en Quercus Suber 1.: evaluación mediante caracteres fisiológicos y marcadores moleculares (Doctoral dissertation, Montes).

Reddy, K.R., and S.K. Matcha. 2010. Quantifying nitrogen effects on castor bean (ricinus communis L.) development, growth, and photosynthesis. Industrial Crops and Products 31(1):185-191. doi:10.1016/j.indcrop.2009.10.004

Rukhsar, M.P. Patel, D.J. Parmar, and S. Kumar. 2018. Genetic variability, character association and genetic divergence studies in castor (Ricinus communis L.), Annals of Agrarian Science 16 (2018):143-148.

Salazar Sánchez L.M., R. Rosales Serna, R. Jimenez Ocampo, J.C. Rios Saucedo, B.A. Bretón Vázquez. 2014. Rendimiento de la higuerilla (Ricinus communis L.) cultivada en dos densidades de población en Durango, México. Agro Faz 14(1):129-135.

Salihu, B.Z., A.K. Gana, and B.O. Apuyor. 2014. Castor oil plant (Ricinus communis L.): botany, ecology and uses. International Journal of Science and Research, 3(5):1333-1341.

Severino, L.S., D.L. Auld, M. Baldanzi, M.J. Cândido, G. Chen, W. Crosby, and O.L. Machado. 2012. A review on the challenges for increased production of castor. Agronomy journal 104(4):853-880.

Shah, S.K., A.V. Joshi, A.M. Patel, and D.K. Patel. 2017. Screening of Castor Genotypes for Ricinoleic Acid Content. International Journal of Current Microbiology and Applied Sciences 6(8):1318-1324.
Sharma, B.R., K.V. Rao, K.P.R. Vittal, Y.S. Ramakrishna, U. Amarasinghe. 2010. Estimating the potential of rainfed agriculture in India. Prospects for water productivity improvements. Agric. Water Manage. 97:23-30. doi: 10.1016/j. agwat.2009.08.002

Shinde, R.S., N.K. Kalegore, and Y.M. Gagare. 2018. Effect of Plant Spacing and Fertilizer Levels on Yield and Yield Attributes of Castor (Ricinus communis L.). International Journal of Current Microbiology and Applied Sciences (2018) Special Issue 6:1738-1743.

Solís-Bonilla. J.L., A. Muñoz Orozco, J.A.S. Escalante Estrada, A. Zamarripa Colmenero. 2016. Growth of varieties and yield components of higuerilla (Ricinus communis L.) in Montecillo, State of Mexico. Revista Mexicana de Ciencias Agrícolas 7(2):311-323

Souza, A.S., F.J.A.F. Tavora, J.B. Pitombeira, F.M.I. Bezerra. 2007. Planting time and irrigation management for castor plant and its effect on growth and productivity. Rev. Cienc. Agronomica 38:422-429.

Souza, S.P., J.E. Seabra, and L.A.H. Nogueira. 2018. Feedstocks for biodiesel production: Brazilian and global perspectives. Biofuels, 9(4):455-478.

Sowmya, P., M. Vanaja, P. Sathish, G.V. Kumar, A. Razak, S. Vaidya, Y. Anitha, P. Satyavathi. 2016. Variability in physiological and yield performance of Castor (Ricinus communis L.) genotypes under rainfed condition of alfisols. Int. J. Plant Breed. Gen. 10:52-57. doi: https://10.3923/ ijpbg.2016.52.57

Teixeira, P. de C., M. Bruno, A.M. Magalhaes, P.R. Ribeiro, D. Takahashi, M.L. Viera, L. Gonzaga, and R. Delmodez. 2017. New insights into the mechanism underlying Ricinus communis $\mathrm{L}$. tolerance to drought stress during germination- Industrial Crops and Products 103(2017):99-106.

Tabarzad, A., and A.A. Ghaemi. 2015. Deficit irrigation and sowing date as strategies to maximize water use efficiency and crop water productivity in semi-arid region. In Biological Forum 7(1):30. 
Turner, N.C. 2018. Turgor maintenance by osmotic adjustment: 40 years of progress. Journal of Experimental Botany 69(13):3223-3233.

UNESCO. 2010. Atlas de Zonas Áridas de América Latina y el Caribe. Dentro del marco del proyecto "Elaboración del Mapa de Zonas Áridas, Semiáridas y Subhúmedas de América Latina y el Caribe" CAZALAC (2010). Documentos Técnicos del PHI-LAC, No. 25
Zhanga T., Y. Hub, K. Zhangc, C. Tianc, J. Guo. 2018 Arbuscular mycorrhizal fungi improve plant growth of Ricinus communis by altering photosynthetic properties and increasing pigments under drought and salt stress. Industrial Crops \& Products 117(2018):13-19. 